\title{
Microgeographic genetic heterogeneity of melanic Daphnia pulex at a low-Arctic site
}

Lawrence J. Weider* and

Paul D. N. Hebert
Department of Biology, University of Windsor, Windsor, Ontario N9B 3P4, Canada.

Clonal diversity of obligately parthenogenetic Daphnia pulex was examined in 147 ponds at 13 sites near Churchill, Manitoba. Cellulose acetate electrophoresis of four polymorphic loci allowed the detection of 16, multi-locus genotypes (clones). The three most common clones accounted for 86 per cent of the 3291 animals surveyed. An average of 1.5 clones coexisted in single ponds, while an average of 3.8 clones was present at each site. Fifteen of the sixteen clones show unbalanced electromorph phenotypes at one or more loci suggesting that they are polyploids. There was significant spatial autocorrelation of the distribution of certain clones within a given site on a scale of tens of metres. Clinal patterns in clone distributions were often found. No significant between-site spatial autocorrelation was found on a scale of 0-20 kilometres, although between-site heterogeneity of clonal frequencies was frequently seen. Microgeographic heterogeneity of $D$. pulex clones at Churchill is influenced by salinity gradients on a scale of tens of meters. Mechanisms that might influence the clonal structure of this apomictic complex are discussed.

\section{INTRODUCTION}

Clonal diversity among parthenogenetic organisms has been well studied (Christensen, 1980; Hebert and Crease, 1980, 1983; Jaenicke et al., 1980; Ochman et al., 1980; Hebert, 1978, 1981; Lynch, 1983; Lyman and Ellstrand, 1984; Rhomberg et al., 1985; Harshman and Futuyma, 1985). Among obligate parthenogens, multiple clones are often present within local populations. For example, Hebert and Crease (1983) observed 22 clones of obligately parthenogenetic Daphnia pulex from ponds near Windsor, Ontario. Clonal diversity estimates for a single habitat (pond) ranged from 1-7 clones $/$ pond $($ mean $=4 \cdot 0$ clones $/$ pond based on 4 enzyme loci). Likewise, Harshman and Futuyma (1985) in a study of the geometrid moth, Alsophila pometaria, observed 70 clones in 22 populations scattered across Long Island. Clonal diversity ranged from 2-15 clones/population (mean $=8 \cdot 4$ clones/population based on 4 enzyme loci).

Most studies of clonal diversity in asexuals have involved temperate zone organisms (Bell,

\footnotetext{
* Present address and reprint requests to: Abteilung Ökophysiologie, Max-Planck-Institut für Limnologie, Postfach 165 , D-2320 Plön, West Germany.
}

1982). Here we examine the genetic structure of melanic, obligately parthenogenetic Daphnia pulex (McWalter, 1981; Hebert and McWalter, 1983) from a low-arctic site. Prior work (Weider and Hebert, 1987) has shown that there is non-random spatial heterogeneity of Daphnia clones in rock pools on three quartzite bluffs (bluffs A, B, and C, fig. 1(b),(c) adjacent to Hudson Bay near Churchill, Manitoba. Clonal distributions are associated with the salinity gradients that are related to distance of a pond from Hudson Bay. This study estimates clonal diversity of melanic $D$. pulex at Churchill and examines clonal distribution patterns on a larger scale of tens of kilometres, and on a microspatial scale of tens of metres.

\section{MATERIALS AND METHODS}

The study area (fig. 1(a) is located at Churchill, Manitoba $\left(58^{\circ} 47^{\prime} \mathrm{N}, 94^{\circ} 11^{\prime} \mathrm{W}\right)$ along a $30 \mathrm{~km} \mathrm{sec}-$ tion of Hudson Bay coast that extends from the west bank of the Churchill River (fig. 1(b), bluff PW) to an area near the National Research Council rocket range (sites C, B, A, EA, and EPA; fig. 1(b). 


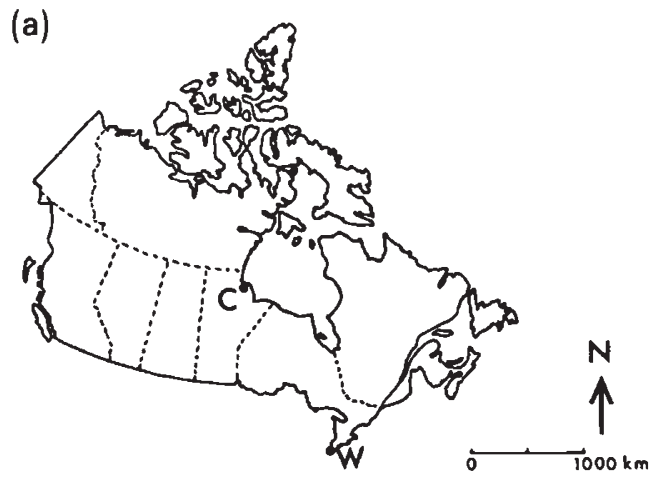

(b)

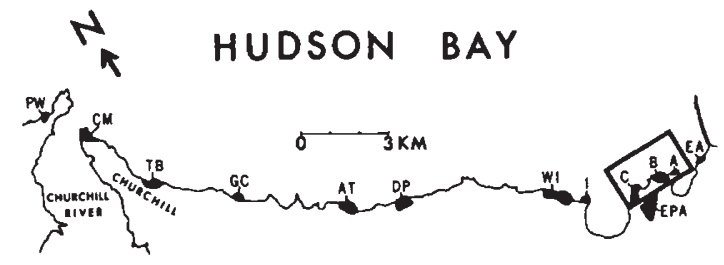

(c)

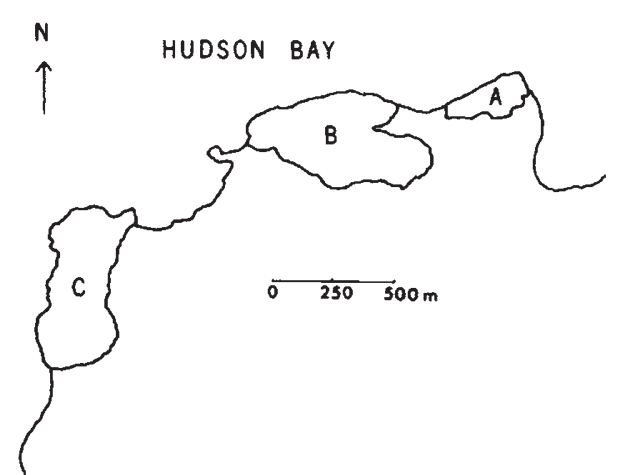

Figure 1 Maps depicting the locations of (a) Churchill, Manitoba (C) and Windsor, Ontario (W); (b) location of sampling sites near Churchill. Abbreviations same as in table 3 legend; (c) map of bluffs A, B, and C that were studied most extensively in 1984, and were used for the within-site spatial analyses.

Melanic Daphnia pulex were surveyed electrophoretically in June-July 1985. More extensive collections from bluffs A, B, and C (fig. 1(c) were made in July 1984 (Weider and Hebert, 1987).

Cellulose acetate electrophoresis (Helena Scientific) was used to determine allozyme phenotypes for individual Daphnia at four polymorphic enzyme loci: PGM (phosphoglucomutase), PGI (phosphoglucose isomerase),
$A O$ (aldehyde oxidase), and GOT (glutamate oxaloacetate transaminase). All electrophoretic methods follow Hebert and Payne (1985), and were modified from Harris and Hopkinson (1976). A more detailed outline of the modifications is available from the authors, upon request.

An electrophoretic survey using an additional 17 enzyme loci (10 were polymorphic; $A C O N 1$ \& 2, AMY 1 \& 2, G6PDH, HEX, LDH, MPI, $P E P$-2, TPI, while FUM, G3PDH, IDH, MDH, $M E, 6 P G D H$, and $X D H$ were monomorphic) examined 118 animals representing 11 four-locus genotypes and failed to detect any additional electrophoretically distinct clones. In previous work (Weider and Herbert, 1987), we report 3 pairs of clones ( 2 and $2 \mathrm{a}, 3$ and $3 \mathrm{a}, 4$ and $4 \mathrm{a}$ ) which varied at only one or two additional loci. (Clones $2 \mathrm{a}, 3 \mathrm{a}$ and $4 \mathrm{a}$ were detected in the 1984 survey, but were not isolated from the 1985 survey.) Therefore, it would be most accurate to view "clones" as clonal groups that consist of one or several closely-related lineages. Estimates of average genetic distance between clones (Nei, 1972) were calculated using single linkage cluster analysis (BMDP, Dixon and Brown, 1979) based on all 21 enzyme loci. Nei's statistics require gene frequency data which in this case were calculated from the genotypes of individual clones.

Animals were collected from a total of 147 ponds located on 12 rock bluffs and an adjacent section of coastal tundra (EPA, fig. 1(b), using a $28 \times 38 \mathrm{~cm}$ (mouth diameter) dip net $(200 \mu \mathrm{m}$ mesh) towed horizontally through the water. No attempt was made to quantify population densities. Ponds were sampled along transects that extended inland from the coast. A total of 3291 animals were sampled in 1985.

Clonal diversity estimates at Churchill were calculated using a random-number generator program on an IBM-PC computer. Presence/absence data for all clones located in all 147 ponds were analysed. The program generated the predicted total number of clones found in single ponds, two-pond combinations, three-pond combinations and so on, up to 147-pond combinations, randomising the pond combinations (100 iterations for each combination). Total number of clones detected vs number of ponds sampled was fitted to a least-squares polynomial regression model.

Spatial autocorrelation analysis (Sokal and Oden, 1978a, b, Cliff and Ord, 1981) was used to determine whether significant spatial patterns exist in clonal distributions, both within and between sampling sites. Within-site spatial autocorrelation was determined for bluffs $\mathrm{A}, \mathrm{B}$, and $\mathrm{C}$ using data 


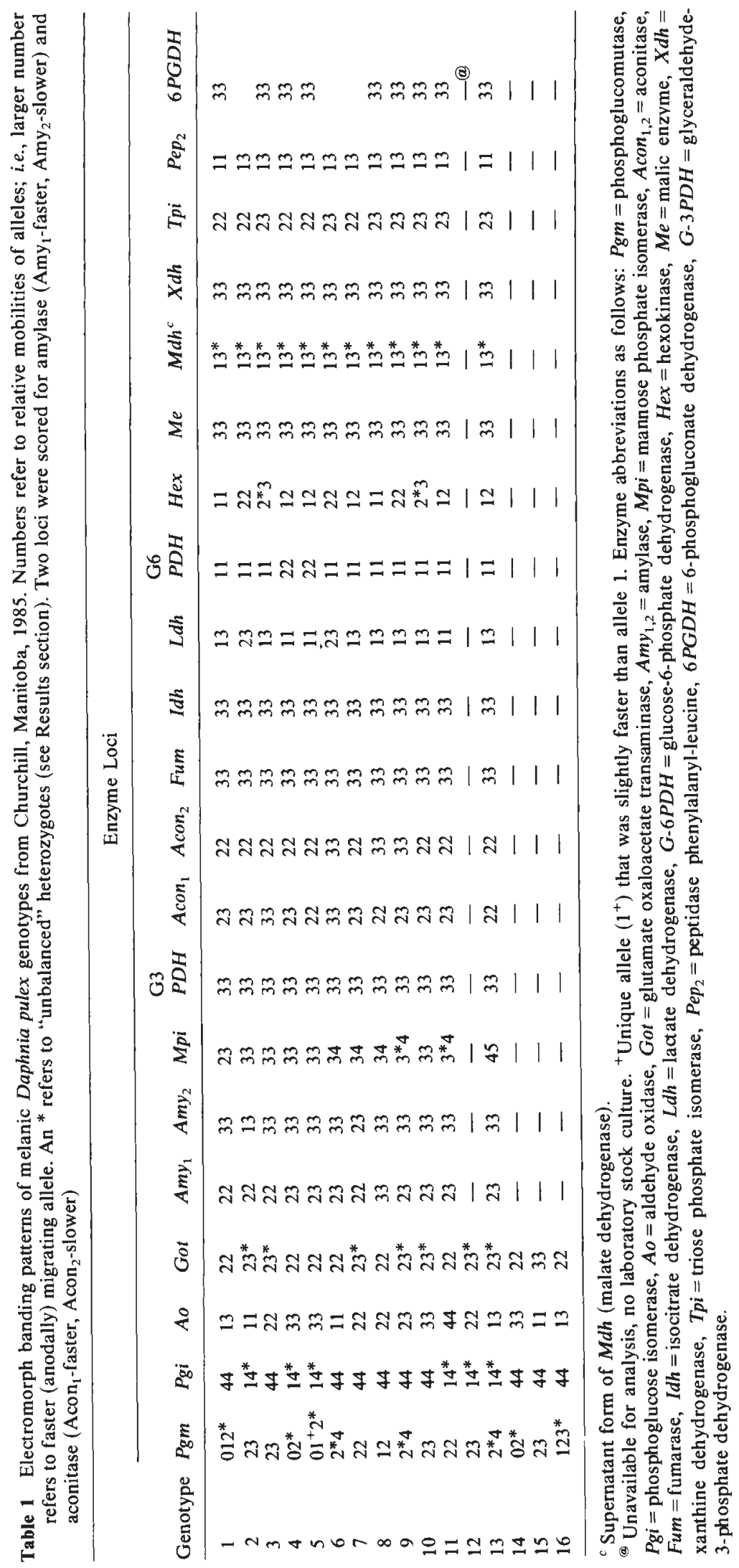


collected in 1984 (Weider and Hebert, 1987). The within-site analysis was restricted to the three most extensively-studied sites. For the between-site analyses, the within-site data were pooled for each bluff. Both within and between-site data were analysed using Spatial Autocorrelation Analysis Program (SAAP, Wartenberg, 1985) on an IBM-PC computer. Spatial autocorrelation coefficients (Moran's I) were determined for the clonal frequencies of the most abundant clones, as a function of distance between sampling sites. Distances were calculated from aerial photographs (National Air Photo Library, Ottawa) using a Bioquant digitiser pad interfaced with an Apple computer. Coordinate $(x, y)$ data were generated for each site (mid-bluff point), as well as for individual ponds on bluffs A, B, and C. Distance class intervals were computer-generated, so that a minimum of 30-40 distance pairs were distributed in each distance class, as suggested by Wartenberg (1985).

RESULTS

\section{Clonal diversity}

Sixteen clones were detected on the basis of the electrophoretic variation at four loci ( $P G M, P G I$, $A O, G O T$; table 1). The three most common clones (clones 1, 3 and 4) accounted for 86 per cent $(N=2817)$ of the animals surveyed $(N=3291$ table 2). Between-site differences in clonal frequencies (table 3 ) were often seen. Clone 3 was the most common clone and was found on all 12 bluffs, but was absent from the EPA tundra ponds. Clone 4 was also absent from the EPA, but was present

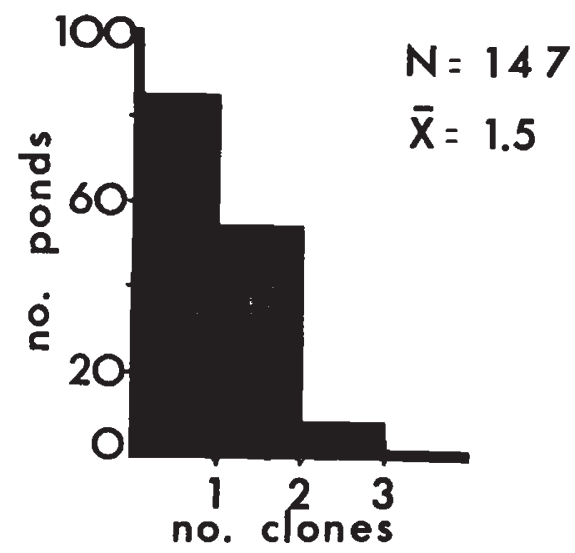

Figure 2 Histogram showing the number of clones detected in each of 147 ponds. Mean number of clones/pond was approximately $1 \cdot 5$.
Table 2 Summary of clonal frequencies of melanic Daphnia pulex, 1985

\begin{tabular}{lrrr}
\hline Clone No. & $N=$ & \% of total & No. of ponds \\
\hline 1 & 674 & 20.5 & 40 \\
2 & 109 & $3 \cdot 3$ & 10 \\
3 & 1475 & 44.8 & 82 \\
4 & 668 & $20 \cdot 3$ & 43 \\
5 & 21 & 0.6 & 3 \\
6 & 72 & $2 \cdot 2$ & 6 \\
7 & 48 & 1.5 & 4 \\
8 & 4 & 0.1 & 2 \\
9 & 120 & 3.6 & 11 \\
10 & 42 & 1.3 & 8 \\
11 & 20 & 0.6 & 2 \\
12 & 2 & 0.05 & 1 \\
13 & 32 & 1.0 & 2 \\
14 & 2 & 0.05 & 1 \\
15 & 1 & 0.05 & 1 \\
16 & 1 & 0.05 & 1 \\
& & & \\
Total & 3291 & 100.00 & \\
\hline
\end{tabular}

in high-salinity ponds near the seaward-side on 10 of 12 bluffs. Clone 1 was found on 7 of 12 bluffs, but was restricted to low-salinity ponds on the landward-side of the bluffs. Clone 1 was very abundant in the EPA tundra ponds. Clone 9 was found on 6 of 12 bluffs, but was not detected at any site east of Ithica Bluff (I). Rare clones $(<2$ per cent of the total sample) were often restricted to a single site (clones 11-16, table 3). Mean clonal diversity at a given site (bluff) was 3.8 clones/site, while mean clonal diversity in a given pond was 1.5 clones/pond (fig. 2).

\section{Allozyme phenotypes}

Six alleles were found at the PGM locus, four at $A O$, and two at $P G I$ and GOT. The homozygotes at $P G I$ were single-banded, while all heterozygotes at $P G I$ were triple-banded, as expected on the basis of the dimeric structure of the enzyme. However, the relative banding intensities did not conform to the expected $1: 2: 1$ ratio. Instead, the staining levels approximated a 9:6:1 ratio. Similar "unbalanced" heterozygotes were observed at GOT. PGM is a monomeric enzyme and heterozygotes ordinarily show two equally staining bands. However, 8 of 14 heterozygotes showed greater activity of one allele product, while several clones $(1,5,16$, Table 1) showed triple-banded phenotypes. The supplemental survey of electrophoretic variation (table 1) revealed "unbalanced" heterozygotes at three additional loci, $H E X, M D H$, and $M P I$. 
Table 3 Clonal frequencies of melanic Daphnia pulex from Churchill, Manitoba, 1985. Sample sizes given in parentheses. Site abbreviations: $P W=$ Prince of Wales (11 ponds); $C M=$ Cape Merry (12); $T B=$ Town Bluff $(20) ; G C=G o l f$ Course $(11)$; $A T=$ Airport (7); $D P=\operatorname{Dump}(2) ; W I=$ West Ithica (6); $I=$ Ithica (10); $C=$ Bluff C (15); $B=$ Bluff B $(16) ; A=B l u f f$ A $(20) ;$ $E A=$ East A (10); EPA = Experimental Ponds Area (7)

\begin{tabular}{|c|c|c|c|c|c|c|c|c|c|c|c|c|c|}
\hline \multicolumn{14}{|c|}{ Sampling Sites } \\
\hline Clone No. & $P W$ & $C M$ & $T B$ & $G C$ & $A T$ & $D P$ & $W I$ & $I$ & $C$ & $B$ & $A$ & $E A$ & $E P A$ \\
\hline 1 & & $\begin{array}{l}0.015 \\
(4)\end{array}$ & $\begin{array}{l}0.202 \\
(98)\end{array}$ & $\begin{array}{l}0.364 \\
(96)\end{array}$ & & & & & $\begin{array}{l}0.319 \\
(107)\end{array}$ & $\begin{array}{l}0.466 \\
(145)\end{array}$ & $\begin{array}{l}0 \cdot 265 \\
(96)\end{array}$ & $\begin{array}{l}0 \cdot 104 \\
(25)\end{array}$ & $\begin{array}{l}0.665 \\
(103)\end{array}$ \\
\hline 2 & & & & & & & & & & & $\begin{array}{l}0.301 \\
(109)\end{array}$ & & \\
\hline 3 & $\begin{array}{l}0.784 \\
(207)\end{array}$ & $\begin{array}{l}0.442 \\
(118)\end{array}$ & $\begin{array}{l}0.324 \\
(157)\end{array}$ & $\begin{array}{l}0.610 \\
(161)\end{array}$ & $\begin{array}{l}0.702 \\
(118)\end{array}$ & $\begin{array}{l}0.479 \\
(23)\end{array}$ & $\begin{array}{l}0.516 \\
(79)\end{array}$ & $\begin{array}{l}0 \cdot 297 \\
(71)\end{array}$ & $\begin{array}{l}0.501 \\
(168)\end{array}$ & $\begin{array}{l}0 \cdot 328 \\
(102)\end{array}$ & $\begin{array}{l}0.169 \\
(61)\end{array}$ & $\begin{array}{l}0.875 \\
(210)\end{array}$ & \\
\hline 4 & $\begin{array}{l}0 \cdot 186 \\
(49)\end{array}$ & $\begin{array}{l}0.416 \\
(111)\end{array}$ & $\begin{array}{l}0.327 \\
(159)\end{array}$ & $\begin{array}{l}0.004 \\
\text { (1) }\end{array}$ & & $\begin{array}{l}0.521 \\
(25)\end{array}$ & $\begin{array}{l}0 \cdot 320 \\
(49)\end{array}$ & $\begin{array}{l}0.598 \\
(143)\end{array}$ & $\begin{array}{l}0.090 \\
(30)\end{array}$ & & $\begin{array}{l}0.265 \\
(96)\end{array}$ & $\begin{array}{l}0.021 \\
(5)\end{array}$ & \\
\hline 5 & & & & & & & & & $\begin{array}{l}0.063 \\
(21)\end{array}$ & & & & \\
\hline 6 & & & & & & & & & $\begin{array}{l}0.024 \\
(8)\end{array}$ & $\begin{array}{l}0.206 \\
(64)\end{array}$ & & & \\
\hline 7 & & & & & & & & & & & & & $\begin{array}{l}0 \cdot 310 \\
(48)\end{array}$ \\
\hline 8 & & & & & & & & & & & & & $\begin{array}{l}0.025 \\
(4)\end{array}$ \\
\hline 9 & $\begin{array}{l}0.007 \\
(2)\end{array}$ & & $\begin{array}{l}0.031 \\
(15)\end{array}$ & $\begin{array}{l}0.018 \\
(5)\end{array}$ & $\begin{array}{l}0.298 \\
(50)\end{array}$ & & $\begin{array}{l}0 \cdot 150 \\
(23)\end{array}$ & $\begin{array}{l}0 \cdot 105 \\
(25)\end{array}$ & & & & & \\
\hline 10 & $\begin{array}{l}0.023 \\
(6)\end{array}$ & & $\begin{array}{l}0.074 \\
(36)\end{array}$ & & & & & & & & & & \\
\hline 11 & & & $\begin{array}{l}0.042 \\
(20)\end{array}$ & & & & & & & & & & \\
\hline 12 & & & & & & & $\begin{array}{l}0.014 \\
(2)\end{array}$ & & & & & & \\
\hline 13 & & $\begin{array}{l}0.120 \\
(32)\end{array}$ & & & & & & & & & & & \\
\hline 14 & & $\begin{array}{l}0.007 \\
(2)\end{array}$ & & & & & & & & & & & \\
\hline 15 & & & & & & & & & $\begin{array}{l}0.003 \\
\text { (1) }\end{array}$ & & & & \\
\hline 16 & & & & $\begin{array}{l}0.004 \\
\text { (1) }\end{array}$ & & & & & & & & & \\
\hline No. of clones & 4 & 5 & 6 & 5 & 2 & 2 & 4 & 3 & 6 & 3 & 4 & 3 & 3 \\
\hline
\end{tabular}

\section{Estimating clonal diversity and relatedness}

Fig. 3 shows that the relationship between number of clones detected and the number of ponds sampled best approximated a power function represented by the equation

$$
Y(\text { clones })=2 \cdot 17 X(\text { ponds }) 0 \cdot 41
$$

$\left(R^{2}=0 \cdot 98\right)$. Seventy-five per cent $(12 / 16)$ of the detected clones were found in the first $60-70$ ponds that were sampled.

Mean genetic distances (fig. 4) between clones (including clones $2 \mathrm{a}, 3 \mathrm{a}$ and $4 \mathrm{a}$; Weider and Hebert, 1987) ranged from $0 \cdot 01-0 \cdot 25$ with a mean value $(+/-1$ S.E.) of $0 \cdot 11+/-0 \cdot 02$. (Clones 12 , 14,15 and 16 were not included in the analysis because laboratory cultures of these rare clones were not isolated). These data indicate a level of genetic differentiation that is intermediate between conspecific populations and "typical sibling species" (Nei, 1972). These estimates of relatedness of clones are relative estimates based on the 21 loci chosen, and are not absolute values. Additional dendrograms might provide an equally acceptable statement of genetic relatedness (Felsenstein, 1985).

\section{Spatial heterogeneity}

Spatial autocorrelation analyses of the within-site clonal frequency data showed that there is significant spatial patterning of certain clones (table 4, fig. 5). On Bluff A, clones 1, 2 and 4 showed significant positive spatial autocorrelation in the smallest distance class $(0-24 \mathrm{~m})$, indicating that ponds in this distance class were more similar in clonal frequencies than ponds outside the distance 


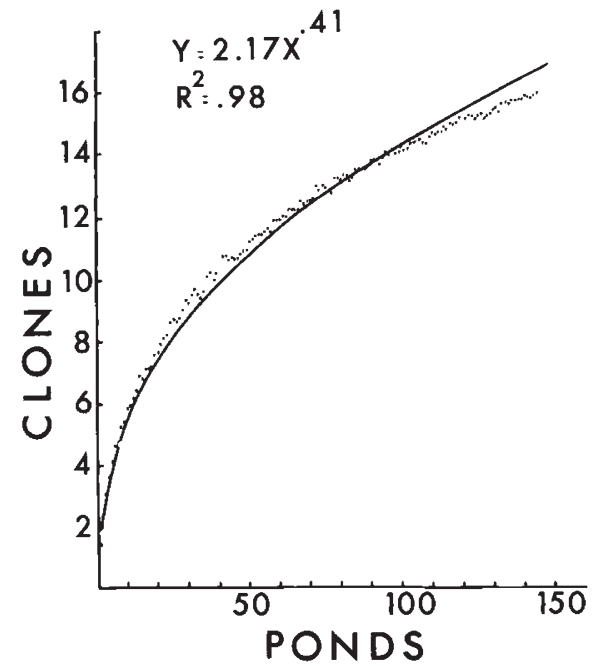

Figure 3 Results of computer analysis showing the relationship between total number of clones detected $(Y)$ and a random sample of different pond combinations $(X)$. The relationship best approximates a power function of $Y=$ $2 \cdot 17 X^{0 \cdot 41}$.

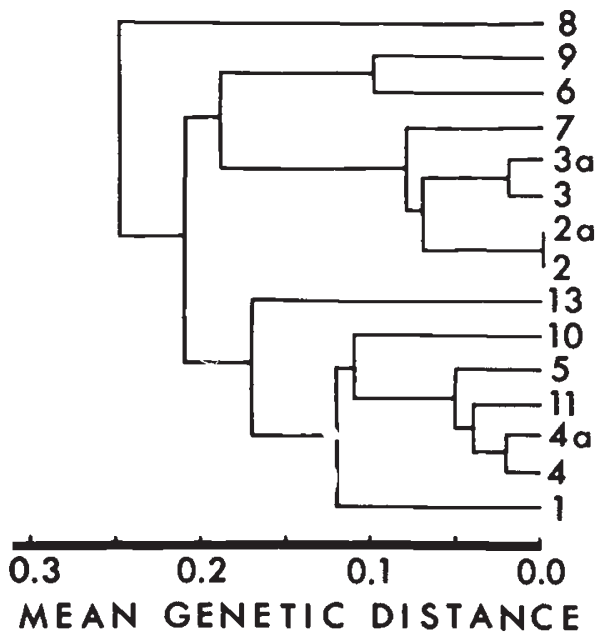

Figure 4 Mean genetic distance dendrogram for melanic Daphnia pulex clones. Numbers $(1,4,4 a, \ldots)$ refer to clones.

class. At larger distances (fig. 5, table 4), the clonal patterns switch to significant negative autocorrelation especially in the largest class (120-144 m). Clone 4 exhibited a clinal pattern to its distribution on Bluff A (fig. 5(a). Interestingly, clone 3 exhibited no significant spatial autocorrelation on Bluff A (fig. 5(a), table 4), but exhibited strong clinal patterns on Bluffs $\mathrm{B}$ and $\mathrm{C}$ as did clone 1 (fig. 5(b), (c). The lack of significant autocorrelation for clone 3 on bluff A may be a consequence (a)

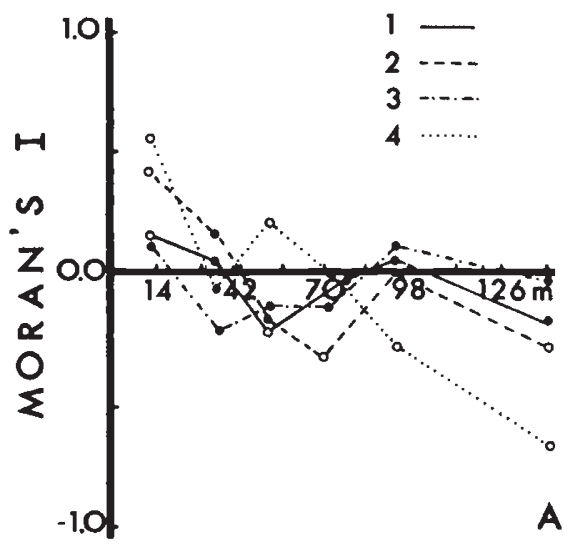

(b)

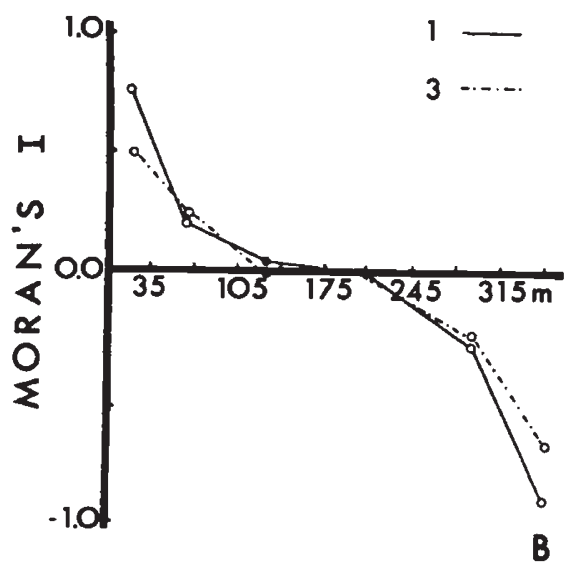

(c)

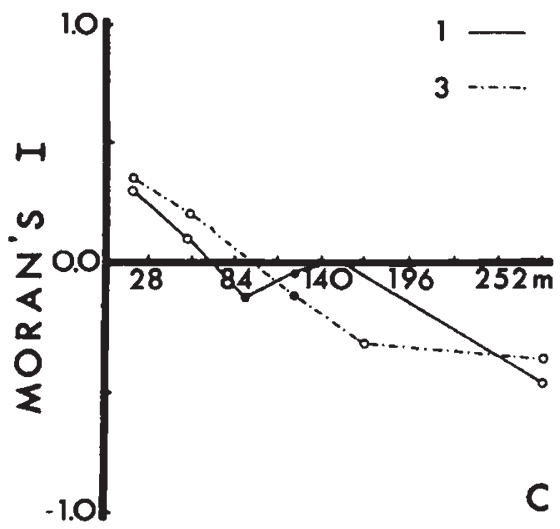

Figure 5 Spatial correlograms depicting the autocorrelation coefficients (Moran's I) as a function of distance between ponds for clonal frequencies of the most common clones (numbers refer to clones) on bluffs A (a), B (b), and C (c). Open circles $=$ significant values (see Table 4). Closed circles $=$ non-significant values. 
Table 4 Spatial autocorrelation statistics (Moran's I) for the clonal frequency data at Churchill, Manitoba collected in 1984 on Bluffs A, B, and C. Within-site spatial patterns were examined

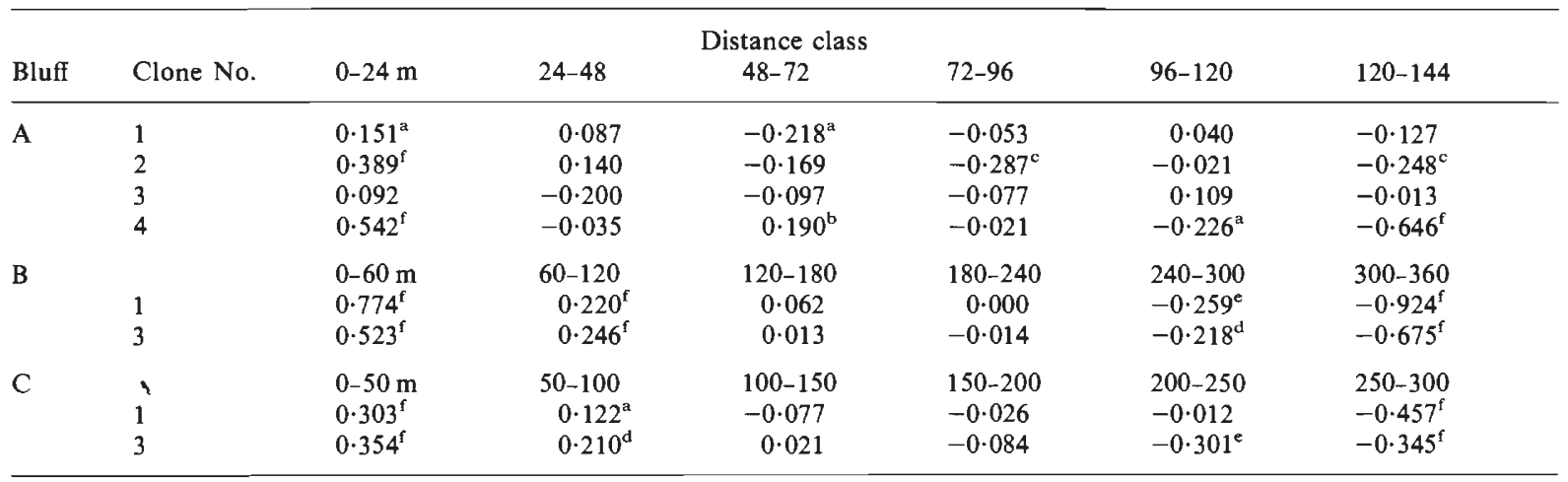

${ }^{\mathrm{a}} P<0.05 .{ }^{\mathrm{b}} \boldsymbol{P}<0.02 .{ }^{\mathrm{c}} \boldsymbol{P}<0.01 .{ }^{\mathrm{d}} \boldsymbol{P}<0.001 .{ }^{\mathrm{e}} \boldsymbol{P}<0.0001 .{ }^{\mathrm{f}} \boldsymbol{P}<0.00002$.

of a scale effect due to the small size of bluff $A$ (total distance on bluff $\mathrm{A}$ of approximately $150 \mathrm{~m}$, as compared to $350 \mathrm{~m}$ and $280 \mathrm{~m}$ on bluffs $B$ and $\mathrm{C}$, respectively).

An examination of between-site clonal frequencies indicated that each of the most common clones (1, 3 and 4$)$ exhibited significant heterogeneity of mean frequencies ( $G$-test, $G=$ 341, 196, 306 respectively; $P<0.001)$. However, when between-site spatial autocorrelation is examined for the three clones on all bluffs, no consistent spatial patterns were observed (table 5).

Table 5 Spatial autocorrelation statistics (Moran's I) for between-site clonal frequency data collected at Churchill, Manitoba in 1985

\begin{tabular}{lrrrr}
\hline Clone & \multicolumn{4}{c}{ Distance class } \\
No. & $0-3.0 \mathrm{~km}$ & $3 \cdot 0-9 \cdot 2$ & $9 \cdot 2-16 \cdot 2$ & $16 \cdot 2-22 \cdot 2$ \\
\hline 1 & 0.059 & -0.267 & 0.113 & -0.290 \\
3 & -0.094 & -0.056 & -0.082 & -0.249 \\
4 & -0.138 & -0.290 & 0.264 & -0.196 \\
\hline
\end{tabular}

\section{DISCUSSION}

The electrophoretic studies indicated that melanic Daphnia pulex at Churchill exhibited unusual allozyme phenotypes. Specifically, all of the clones showed "unbalanced" heterozygote phenotypes at one or more loci, and several clones exhibited three-banded heterozygotes at the monomeric $P G M$ locus. Such phenotypes suggest that these clones are polyploids, and DNA-quantification studies (Hebert, 1986; M. Beaton, pers. comm.) have indicated that all the clones included in this survey are tetraploids $(4 n)$.
The clonal diversity surveys at Churchill revealed an average of 1.5 clones/pond, with a total of 16 clones detected from the Churchill area. These 16 clones showed considerable differences in both relative abundance (table 2), as well as in distributions (table 3). Generally, there are about 3 clones/pond in obligately asexual populations of $D$. pulex from sites in both southern Ontario and the western arctic (Hebert and Crease, 1980, 1983; Hebert and Loaring, 1986). An analysis of 65 populations in southwestern Ontario revealed 36 clones (Hebert et al., in preparation). On this basis, melanic $D$. pulex populations at Churchill are considerably less clonally diverse than other populations of obligately parthenogenetic $D$. pulex, both on a microscale (single pond) and localised scale (tens of kilometres).

The present study has clearly not identified all clones in the Churchill area. As mentioned above, three clones (2a, 3a and 4a; fig. 4) are closelyrelated to clones 2, 3 and 4, respectively, and may represent mutationally-derived lineages. Additional "mutationally-derived" clones would undoubtedly be detected if more loci were surveyed. Our clonal diversity estimates at Churchill are in this sense conservative. To detect additional independently-derived lineages in the Churchill area would not be easy.

The source of clonal diversity in this apomictic complex remains unclear. Parker (1979) considers some of the ecological and evolutionary implications of multiclonal "morphospecies" and concludes that their mode of origin as mono- or polyphyletic groups is important in determining the nature of the selective forces operating on clonal arrays. Clones that arise through polyphyletic origins from the same sexual species differ at many loci, and may differ in fitness attributes such 
as life history characters. Such clones may be adapted to different microhabitats, and may have reduced niche overlap. In contrast, mutationallyderived clones from a single ancestral lineage with a monophyletic origin may initially show no fitness or ecological differences because single gene differences may not be expressed phenotypically. The genetic divergence among clones found at Churchill is compatible with a polyphyletic origin. The loss of sex in the Churchill $D$. pulex complex is probably the result of sex-limited suppressors of meiosis (Hebert, 1981, 1986; Innes and Hebert, in review), and such suppressors provide a mechanism for the polyphyletic loss of sex.

Spatial patterning of clones showed significant within-site spatial autocorrelation on a scale of tens of metres (table 4; fig. 4). There is in addition an association between salinity gradients and clonal distributions of melanic $D$. pulex at Churchill. Differences in salinity tolerance between clones suggest that this Daphnia "complex" has differentiated into physiologically distinct ecotypes (Weider and Hebert, 1987). Withinsite variation in clonal distributions are influenced strongly by spatial patterning of selective forces (i.e., salinity gradients). Additional selective factors such as invertebrate predators may also be important (personal observation). Both within-site and between-site spatial patterns imply that patterning of selective factors is on a much smaller scale than inter-site distance (tens of metres versus kilometres). This might explain why no consistent between-site clonal patterns were found (table 5).

Although no significant between-site autocorrelation was detected (scale of $0-20 \mathrm{~km}$; table 5), there was considerable between-site heterogeneity of clones. This spatial heterogeneity is probably related to environmental heterogeneity. For example, clone 1 was found at a lower frequency on bluff A (table 3), than on bluffs B and $C$, perhaps because of the higher salinity of pond water on bluff $A(2390+/-558 \mu \mathrm{S} / \mathrm{cm}$ on A; $469+/-68 \mu \mathrm{S} / \mathrm{cm}$ on B; $1208+/-246 \mu \mathrm{S} / \mathrm{cm}$ on $\mathrm{C}$ ). However, other distributional patterns are more difficult to explain. For instance, clone 2 was found in 10 of 20 ponds on bluff A (table 3), but was not detected on any other bluff. Additional environmental factors that influence pond water quality such as nutrient input may be involved.

If clonal diversity patterns at Churchill are in equilibrium, then present levels of clonal diversity are a product of the interaction between diversitygenerating and diversity-reducing processes. Diversity may be increased by the dispersal of new clones into the region, and by the creation of new clones in situ. Such new clones might arise from the mutational divergence of existing lineages, or by the formation of new lineages. Despite the absence of cyclically parthenogenetic lines of $D$. pulex in the Churchill area, a number of melanic (polyploid) and non-melanic (diploid) obligately parthenogenetic clones have retained the ability to produce males (personal observations). It is possible that polyploid melanic clones may have been produced through hybridisation between diploid clones resulting in the present clonal array.

The elucidation and measurement of diversityreducing processes such as competitive exclusion, differential predation, and elimination of clones (through stochastic forces) requires further research. The maintenance of clonal diversity in the Churchill region appears to be linked to spatial (and to a lesser extent temporal) heterogeneity in the environment. Further study of the processes that maintain clonal diversity and influence clonal distributions is needed.

Acknowledgements We thank Neil Billington and Nancy Zehrbach for field assistance, and Margaret Beaton and David Innes for computer assistance. David Innes, Robert Ward, and an anonymous reviewer provided valuable comments on an earlier version of the manuscript. This research was supported by a Natural Sciences and Engineering Research Council grant to P.D.N.H.

\section{REFERENCES}

BELL, G. 1982. The Masterpiece of Nature: The Evolution and Genetics of Sexuality, Univ. Calif. Press, Berkeley.

CHRISTENSEN, B. 1980. Constant differential distribution of genetic variants in parthenogenetic forms of Lumbricillus lineatus (Enchytraedae: Oligochaeta). Hereditas, 92, 193198.

Cliff, A. D. AND ORD, J. K. 1981. Spatial Processes: Models and Applications, Pion, London.

DIXON, W. J. AND BROWN, M. B. 1979. Biomedical Computer Programs P-Series, University of California Press, Los Angeles.

FELSENSTEIN, J. 1985. Confidence limits on phylogenies: an approach using the bootstrap. Evolution, 39, 783-791.

HARRIS, H. AND HOPKINSON, D. A. 1976. Handbook of Enzyme Electrophoresis in Human Genetics, American Elsevier, New York

HARSHMAN, L. G. AND FUTUYMA, D. J. 1985. The origin and distribution of clonal diversity in Alsophila pometaria (Lepidoptera: Geometridae). Evolution, 39, 315-324.

HEBERT, P. D. N. 1978. The population biology of Daphnia (Crustacea, Daphnidae). Biol. Rev., 53, 387-426.

HEBERT, P. D. N. 1981. Obligate asexuality in Daphnia. Am. Nat., 117, 784-789.

HEBERT, P. D. N. 1986. Genotypic characteristics of the Cladocera. Hydrobiol, in press.

HEBERT, P. D. N. AND CREASE, T. J. 1980. Clonal coexistence in Daphnia pulex (Leydig): Another planktonic paradox. Science, 207, 1363-1365. 
HEBERT, P. D. N. AND CREASE, T. 1983. Clonal diversity in populations of Daphnia pulex reproducing by obligate parthenogenesis. Heredity, 51, 353-369.

HEBERT, P. D. N. AND MCWALTER, D. B. 1983. Cuticular pigmentation in arctic Daphnia: adaptive diversification of asexual lineages? Am. Nat., 122, 286-291.

HEBERT, P. D. N. AND PAYNE, W. J. 1985. Genetic variation in populations of the hermaphroditic flatworm Mesostoma lingua (Turbellaria; Rhabdocoela). Biol. Bull., 169, 143151.

HEBERT, P. D. N. AND LOARING, J. M. 1986. Systematics of the Daphnia pulex group: variation in an agamic complex and description of a species new to North America. Biochem, Syst. Ecol., 14, 333-340.

JAENICKE, J., PARKER, E. D. JR. AND SELANDER, R. K. 1980. Clonal niche structure in the parthenogenetic earthworm, Octolasion tyrtaeum. Am. Nat., 116, 196-205.

LYMAN, J. C. AND ELLSTRAND, N. C. 1984. Clonal diversity in Taraxacum officinale (Compositae), an apomict. Heredity, 53, 1-10.

LYNCH, M. 1983. Ecological genetics of Daphnia pulex. Evolution, 37, 358-374.

MCWALTER, D. B. 1981. Genetic variation and relatedness of asexual Daphnia species. M.Sc. thesis, University of Windsor, Canada.
NEI, M. 1972. Genetic distance between populations. Amer. Nat., 106, 283-292.

OCHMAN, H., STILLE, B., NICKLASSON, M., SELANDER, R. K., AND TEMPLETON, A. R. 1980. Evolution of clonal diversity of the parthenogenetic fly Lonchoptera dubia. Evolution, 34, 539-547.

PARKER, E. D. JR. 1979. Ecological implications of clonal diversity in parthenogenetic morphospecies. Am. Zool., 19, $753-$ 762.

RHOMBERG, L. R., JOSEPH, S., AND SINGH, R. S. 1985. Seasonal variation and clonal selection in cyclically parthenogenetic rose aphids (Macrosiphum rosae). Can. J. Genet. Cytol., $27,224-232$.

SOKAL, R. R. AND ODEN, N. L. 1978a. Spatial autocorrelation in biology. 1. Methodology. Biol. J. Linn. Soc., 10, 199-228.

SOKAL, R. R. AND ODEN, N. L. $1978 \mathrm{~b}$. Spatial autocorrelation in biology, 2. Some biological applications of evolutionary and ecological interest. Biol. J. Linn. Soc., 10, 229-249.

WARTENBERG, D. E. 1985. Spatial autocorrelation as a criterion for retaining factors in ordinations of geographic data. Math. Geol., 17, 665-682.

WEIDER, L. J. AND HEBERT, P. D. N. 1987. Ecological and physiological differentiation among low-arctic clones of Daphnia pulex. Ecology, 68, 188-198. 